\title{
KONTRIBUSI EVENT MARKETING TERHADAP EKUITAS MEREK KOTA SOLO
}

\author{
Oleh \\ Candra Yudha Satriya \\ Mahasiswa Program S2 Komunikasi Strategis Angkatan V \\ Pasca Sarjana Universitas Diponegoro
}

\begin{abstract}
Events marketing have grown in the tourism industry as indispensable product alternatives to attract many visitors. Also in Solo, from small traditional cultural events to mega-events such as International conference or PARA Games, events have been used as products to generate additional visits to Solo. Special tourism events can greatly contribute to the overall marketing of the destination by helping to create an image for the city. They can be used to help promote, position, and brand a destination. With brand equity conceptual approach, this paper discusses the roles events can play in Solo branding strategies. More specifically, it examines event marketing's contributions to Solo's awareness, perceived quality, brand associations, loyalty, and positioning
\end{abstract}

\section{Abstraksi}

Event marketing telah tumbuh dalam industri pariwisata sebagai alternatif produk wisata yang sangat diperlukan untuk menarik wisatawan. Hal tersebut juga diadopsi oleh kota Solo. Dari mementaskan acara-acara kecil yang bersifat kebudayaan dan tradisi sampai menjadi tuan rumah mega-event seperti konferensi internasional atau Olimpiade PARA Games, event marketing telah digunakan sebagai daya tarik untuk menghasilkan kunjungan tambahan ke kota Solo. Event-event tersebut bisa memberikan kontribusi besar terhadap tercapainya tujuan pemasaran secara umum dengan membantu memperkuat citra. Serta juga bisa digunakan untuk membantu mempromosikan, memposisikan, dan memperkuat merek kota Solo. Dengan pendekatan konseptual ekuitas merek, paper ini membahas peran event marketing terhadap strategi branding kota Solo. Lebih khusus lagi, mengkaji kontribusi pelaksanaan event marketiing terhadap awareness, persepsi kualitas, asosiasi merek, loyalitas, dan positioning kota Solo.

Keywords: pemasaran pariwisata; event marketing; brand equity Solo

PENDAHULUAN

\section{Event Marketing}

Setiap kota akan berusaha menyusun strategi pemasaran yang dapat menjangkau target marketnya dengan seefektif mungkin. Berbicara tentang komunikasi yang efektif, salah satu alat bauran pemasaran yang merupakan sarana kota sebagai destinasi wisata untuk berkomunikasi dengan konsumennya adalah promosi. Menurut Fendi Tjiptono 
(1997:219) promosi adalah suatu bentuk komunikasi pemasaran, yaitu aktivitas pemasaran yang berusaha menyebarkan informasi, mempengaruhi atau membujuk dan mengingatkan pasar atas perusahaan dan produknya agar bersedia menerima, membeli dan loyal pada produk yang ditawarkan. Promosi merupakan salah satu faktor penentu keberhasilan suatu program pemasaran. Apabila konsep promosi tersebut sesuai dengan target market maka dapat membangun dan memperkuat kepercayaan konsumen terhadap produk maupun citranya. Kota yang dianggap memiliki ekuitas merek tinggi akan menyebabkan pangsa pasar dan harga jualnya lebih tinggi daripada kota-kota pesaing, apabila kota tersebut juga memiliki loyalitas konsumen tinggi, kesadaran nama tinggi, kualitas mutu yang dirasakan tinggi, asosiasi merek kuat, dan aset-aset lainnya (Aaker, 1991).

Dewasa ini, salah satu dari program promosi yang sering diadakan oleh kota sebagai sebuah destinasi pariwisata, adalah mengadakan kegiatan-kegiatan promosi yang membutuhkan keterlibatan masyarakat secara langsung (marketing event). Marketing event telah tumbuh pesat sebagai alternatif tujuan wisata di berbagai daerah. Marketing event ini telah digunakan sebagai produk pariwisata untuk menghasilkan kunjungan tambahan ke tempat wisata. Dan faktanya, apabila dikelola dengan tepat, marketing event bisa menghasilkan efek yang luar biasa terhadap tingginya tingkat kunjungan, liputan media, prestise, citra, atau dampak ekonomi lainnya bagi masyarakat setempat (Getz 1997:6). Selain citra dan manfaat pariwisata lainnya, event yang berskala besar seperti
Pesta Olimpiade Olah Raga juga dapat berfungsi sebagai katalis bagi pembaruan perkotaan dan pengembangan infrastruktur baru dalam kota tersebut. Ataupun paling tidak. ada tujuan sederhana yang bisa dikemukakan dalam event pariwisata yaitu dapat menempatkan atau mencantumkan kota tersebut pada peta perjalanan wisata yang secara langsung akan bisa menarik wisatawan. Menurut Belch (2012;549), Event marketing is a type of promotion where a company or brand is linked to an event or where a themed activity is developed for the purpose of creating experiences for consumers and promoting a product or service. Para pelaku pemasaran seringkali melakukan kegiatan event marketing dengan mengasosiasikan dengan aktifitas-aktifitas yang popular, misalnya event olah raga, konser musik, budaya, bazaar, festifal serta fair. Bagi wisatawan, event marketing adalah kesempatan untuk bersantai, relaksasi, bersosialisasi, dan berbudaya di luar kegiatan normal yang dilakukan dalam kehidupannya sehari-hari. Event Marketing selalu bersifat terencana, menimbulkan harapan tertentu, dan juga bersifat memotivasi karena selalu memberikan alasan kenapa perayaan tersebut dilakukan.

Surakarta atau Solo adalah kota di Jawa Tengah yang tengah menjadi salah satu ikon dalam promosi pariwisata Indonesia. Strategi komunikasi pariwisata kota Solo dikelola oleh Dinas Kebudayaan dan Pariwisata Kota Solo yang berperan sebagai National Tourism Organization. Berbagai kegiatan difokuskan pada kegiatan yang berujung pada kota event atau lebih luas dikenal dengan kota MICE (Meeting, incentive, convention, and exhibition). Solo 
tidak memiliki lahan pertanian sehingga tidak heran jika kota ini menggantungkan pendapatan dari sektor perdagangan dan jasa, terutama di bidang pariwisata, seperti hotel dan restoran. Memosisikan diri sebagai kota event membuat Solo kerap dijadikan kota penyelenggaraan kegiatan dan pameran bertaraf nasional, bahkan internasional

Jenis Event sangatlah bervariasi, termasuk festival, pameran, meeting atau acara bisnis dan pendidikan, acara olahraga, serta seni pertunjukan. Event marketing yang dilakukan oleh kota Solo sebagai lini produk destinasi wisata memang diakui sebagai bentuk promosi yang cukup menonjol, dan mendapatkan banyak perhatian. Event marketing reguler kota Solo terkait dengan budaya yang terbesar diantaranya penyelenggaraan Solo Batik Carnival (SBC), Solo International Performing Art (SIPA) dan Surakarta International Ethnic Music (SIEM), serta International Keroncong Festival (IKF).

Untuk mencapai tujuan pemasaran kota Solo yang diwujudkan dalam pelaksanaan event marketing, maka harus dilakukan suatu perencanaan yang matang. Menurut J.R Rossister dan L.Percy (1996:346) perencanaan event marketing menyangkut: Target audience reach, Compability with the Company's or Brand positioning, Message capasity. Target audience reach adalah segmen yang akan dicapai oleh perusahaan. Dalam memilih jenis event marketing yang akan diselenggarakan perlu diperhatikan segmen mana yang akan dicapai oleh kota Solo. Sebagai contoh Solo ingin meraih segmen pasar wisatawan nusantara, perkotaan, SES $\mathrm{AB}$, maka kota Solo akan membuat event atau acara-acara yang disukai oleh golongan segmentasi tersebut (konser dan event-event budaya,dll). Compability with the Company's or Brand positioning adalah posisi brand kota Solo dimata konsumen. Tagline Kota Solo sebenarnya sudah diluncurkan yaitu "Solo the Spirit of Java". Pesan budaya yang ingin diwujudkan adalah bagaimana mewujudkan "Solo ke depan adalah Solo masa lalu" sebagai bentuk ikon turunan dari Solo the Spirit of Java dalam mewujudkan visi misinya. Serangkaian kegiatan dilakukan dalam rangka menjual Kota Solo sebagai kota budaya. Dibutuhkan konsep pemasaran yang disusun berdasarkan potensi kota yang dimiliki. Sebagai kota budaya merupakan salah satu visi yang dimiliki oleh Kota Solo. Untuk mewujudkan visi Kota Solo, diperlukan misi yang dapat diimplementasikan ke dalam seluruh aspek dan elemen masyarakat dengan beberapa cara. Ataupun strategi. Dengan ikon "Solo masa depan adalah Solo masa lampau" mengisyaratkan adanya upaya untuk mewujudkan kesejahteraan dan kejayaan pada masa lalu yang diwujudkan kembali dengan pemikiran, aktifitas dan simbol saat ini dengan nilai-nilai budaya yang dimiliki. Oleh karena itu, program dan strategi event marketing yang dilakukan adalah kegiatan yang secara langsung membantu menajamkan image kota Solo sebagai jiwanya orang Jawa. Message capasity adalah seberapa besar kemungkinan pesan yang akan disampaikan kota Solo lewat kegiatan event marketing tersebut bisa tersampaikan kepada khalayak. Misalnya pada event olah raga, kota Solo sebagai tuan rumah ASEAN Para Games 2011 mendapatkan publisitas media dan juga 
branding yang maksimal terkait dengan penyelenggaraan event tersebut.

\section{Tujuan penggunaan Event Marketing}

Tujuan kota Solo dalam mengatur, mempromosikan, dan menjalankan event marketing sebagai bagian dari strategi promosinya, adalah antara lain sebagai daya tarik utama para wisatawan yang belum pernah datang ke kota Solo, untuk merasakan sensasi pengalaman berwisata di kota Solo. Dengan dilaksanakannya event marketing, seperti misalnya pameran seni atau acara olah raga, bisa menarik para wisatawan yang belum pernah mengunjungi kota Solo, untuk datang ke event tersebut sambil menikmati pengalaman pertamanya mengunjungi kota Solo. Selain itu, event marketing juga bisa digunakan untuk menyediakan tempat alternative untuk berwisata pada saat kota Solo tidak banyak dikunjungi wasatawan (off season). Sebuah marketing event juga dapat menghasilkan permintaan tambahan pada saat musim wisata untuk membantu meningkatkan kedatangan dan tingkat hunian di hotel . Selain itu, marketing event dapat mendorong wisatawan reguler untuk memperpanjang masa tinggalnya di Solo dalam rangka untuk menghadiri acara atau pertunjukan tersebut walaupun sebenarnya mereka tidak merencakan untuk menghadiri eventnya. Namun, kelemahan potensi event marketing adalah dengan adanya event tersebut bisa mempengaruhi pindahnya keputusan untuk mengunjungi kota Solo ke kota wisata lainnya. Sebagai contoh, beberapa wisatawan yang biasa mengunjungi kota Solo di akhir minggu terpaksa membatalkan rencananya karena adanya event Solo Batik Carnival, yang dikarenakan takut akan harga hotel yang lebih tinggi ataupun lalu lintas yang padat.

Event marketing merupakan suatu kegiatan yang dapat menjadikan kota Solo tetap selalu diingat dan dapat juga dapat meningkatkan citra. Event marketing diselenggarakan dengan tujuan agar nama kota Solo menjadi lebih dikenal dan mendapat citra yang baik dari target pasar. Event ini juga dimaksudkan untuk membangun dan memperkuat kepercayaan konsumen terhadap brand image kota Solo. Dengan brand image yang kuat akan membedakan kota Solo dengan kota pesaing, karena pada dasarnya, brand image suatu kota tidak dapat disamakan dengan brand image kota lain.

Event marketing merupakan salah satu kegiatan promosi yang dianggap efektif sebagai strategi komunikasi bisnis industri destinasi wisata agar namanya bisa dikenal di masyarakat dan sekaligus melakukan publisitas (Stanton, 1993:140). Dengan adanya event tersebut, media massa akan meliputnya tanpa kita harus membayar biaya ruang media, dan liputan tersebut akan didengar, dilihat dan dibaca oleh masyarakat. Keunikan event-event di kota Solo juga mengundang perhatian media massa untuk meliput dan mempublikasikan melalui berita yang dimuat di media massa. Publikasi media massa terhadap event marketing kota Solo diharapkan dapat membantu dalam upaya membangun dan memperkuat kepercayaan wisatawan terhadap brand image kota Solo, karena publisitas media massa memiliki cakupan yang luas, dan informasi media massa dianggap sebagai informasi yang berasal dari luar yang memiliki nilai berita yang 
tidak bisa dikendalikan dan tidak dibayar oleh sumber tersebut yang ingin mempublikasikan eventnya.

Salah satu kelebihan dari penyelenggaraan event marketing ini adalah sifat dari event marketing itu sendiri yang sangat fleksibel. Event marketing dapat sewaktu-waktu berubah menyesuaikan dengan perubahan kebutuhan konsumen, event juga dapat disesuaikan dengan target pasar yang diiginkan, serta bisa disesuaikan dengan kebutuhan saat ini, gaya hidup, dan tren atau mode terbaru. Event marketing bisa dianggap sebagai peluang promosi yang cukup efektif bagi kota Solo sebagai jalan untuk membentuk asosiasi merek kota Solo yang disesuaikan dengan gaya hidup atau keadaan tertentu. Sebagai contoh, program acara musik internasional seperti SIEM (Solo International Ethnic Music) yang mengasosiasikan kota Solo sebagai kota budaya yang menjadikan music etnik jawa sebagai jati diri atau identitas.

Yang tak kalah pentingnya, event marketing bisa sangat berkontribusi terhadap tujuan pemasaran destinasi wisata kota Solo secara keseluruhan dengan membantu menciptakan atau mempertahankan citra kota Solo. Lebih khusus lagi, event marketing dapat digunakan untuk membantu mempromosikan dan memposisikan brand kota Solo. Dan juga mampu untuk menyampaikan dan mengkomunikasikan brand image kota Solo secara efektif kepada target khalayak. Sayangnya, memasarkan kota Solo sebagai produk destinasi wisata, dan lebih khusus lagi membuat positioning-nya, yang meliputi strategi diferensiasi produk yang koheren dan segmentasi pasar, belum banyak menjadi perhatian dari Badan Promosi Pariwisata Daerah Solo (BPPIS) ataupun Dinas Kebudayaan dan Pariwisata (Disbudpar) Kota Solo, yang mana secara tradisional masih berfokus pada dimensi fungsi promosi pemasaran saja.

\section{Apa yang bisa menarik bagi wisatawan.}

Pada umumnya, apa yang telah ditekankan oleh para pemangku kebijakan promosi pariwisata di kota Solo, terkait dengan strategi pembuatan iklan promosi pariwisatanya, masih banyak kekurangan dan tidak tepat sasaran. Artinya, para wisatawan, sebagai target utama dari iklan tersebut, tidaklah termotivasi untuk datang ke suatu obyek dikarenakan oleh fitur-fitur kualitas dari obyek tersebut, melainkan disebabkan adanya kecocokan antara atribut utama obyek tersebut dengan kebutuhan psikologis para wisatawan. Lawton dan Page (1997) berpendapat bahwa dalam beberapa tujuan wisata perkotaan, mungkin ada ketidakcocokan antara atribut produk destinasi wisata yang dipromosikan dengan citra destinasi wisata yang digunakan untuk menarik wisatawan. Sebuah produk destinasi wisata tidak selalu memotivasi wisatawan untuk berkunjung, tetapi dari pengalaman kunjungan merekalah motivasi berkunjung itu biasanya timbul. Oleh karena itu dibutuhkanlah kecocokan antara atribut destinasi wisata dengan keinginan pasar yang disasar. Secara umum, ada kecenderungan trend perpindahan dari atribut produk destinasi wisata menuju gaya hidup atau sistem nilai. Ditambah lagi, para konsumen dewasa ini semakin cerdas, mereka membuat pilihan berdasar pada cocok tidaknya sebuah produk terhadap 
dirinya atau gaya hidupnya, apakah itu merupakan hal baru yang menarik bagi dirinya ataupun merupakan sebuah ekspektasi pengalaman.

\section{Kota Solo sebagai Brand dan Brand Equity}

Ritchie dan Ritchie (1998) menunjukkan bagaimana definisi merek destinasi wisata ini bisa berkembang dan berevolusi menjadi cerminan dari kebutuhan konsumen akan brand experience. Pada awalnya mereka berpendapat, secara umum, bahwa merek sebuah destinasi wisata adalah nama atau simbol tertentu yang dimaksudkan untuk mengidentifikasi destinasi wisata dan untuk membedakannya dari destinasi wisata pesaing. Tetapi kemudian mereka menambahkan akan pentingnya pengalaman atau experience, bahwa sebuah brand destinasi wisata adalah nama, simbol, logo, tanda atau bentuk grafis lainnya yang mengidentifikasi dan membedakan sebuah destinasi wisata, lebih lanjut, juga disampaikan janji pengalaman wisata yang tak terlupakan yang terasosiasi secara unik dengan destinasi wisata tersebut, dan juga berfungsi untuk memperkuat ingatan serta kenangan yang menyenangkan dari pengalaman terkait destinasi wisata tersebut.

Beberapa penulis dalam literatur pemasaran telah mengidentifikasikan lebih jauh tentang konsep brand equity dan brand identity,misalnya Aaker (1991), menyebutkan bahwa brand leadership merupakan penentu untuk sebuah keberhasilan kompetitif. Berdasarkan Aaker pula, kita dapat mendefinisikan brand equity destinasi wisata sebagai aset merek (atau liabilitas) terkait dengan nama dan simbol destinasi wisata yang menambah (atau mengurangi) layanan serta pengalaman yang disediakan. Selanjutnya, band equity destinasi wisata bisa dihasilkan dari kombinasi loyalitas terhadap destinasi wisata tersebut, kesadaran merek (awareness), persepsi kualitas (perceived quality), asosiasi merek (brand association), dan aset lainnya seperti keunggulan kompetitif (competitive advantage) yang tercipta oleh merek.

Di industri pariwisata, merek bisa menjadi kunci utama dari keunggulan kompetitif. Bagi pemasar pariwisata, kesulitannya adalah lebih ke proses evaluasi dan menilai aset tidak berwujud seperti merek. Namun, pentingnya arti merek dan kontribusinya terhadap daya saing kota Solo seharusnya menjadikan hal tersebut menjadi tidak perlu untuk diperdebatkan. Oleh karena itu, proposisi ataupun pernyataan yang dinyatakan dalam paper ini adalah event marketing merupakan kunci penting untuk pemasaran pariwisata dan memiliki potensi yang sangat efektif untuk memberi nilai tambah terhadap ekuitas merek kota Solo.

\section{Tujuan penulisan}

Event marketing berfungsi memberikan kesempatan bagi pemasar untuk membantu memposisikan destinasi wisata mereka dengan produk dan layanan (event) yang dapat disesuaikan untuk memenuhi kebutuhan target pasarnya. Event yang awalnya hanya merupakan ekspresi budaya suatu daerah berkembang menjadi alat pemasaran yang utama, yang 
digunakan untuk membangun citra dan posisi kota Solo di antara pesaingnya. Event marketing memiliki potensi untuk menjadi alat pemasaran yang efektif untuk memasarkan kota Solo, karena event mempunyai daya tarik untuk menarik wisatawan dengan konten ataupun fiturfitur khusus dari event tersebut. Oleh karena itu, event lebih cenderung bertujuan untuk memenuhi kebutuhan wisatawan. Lebih khusus lagi, jika kita asumsikan bahwa kota-kota ataupun destinasi wisata lainnya dianggap sebagai merek, akan menjadi sangat penting untuk memastikan bagaimana sebuah event bisa berkontribusi terhadap ekuitas merek destinasi wisata. Tujuan dari paper ini adalah untuk membahas aspek tujuan pemasaran, dan untuk menunjukkan bagaimana event marketing bisa berkontribusi untuk membangun ekuitas merek kota Solo.

\section{PEMBAHASAN}

\section{Peran Event Marketing dalam memasarkan kota Solo.}

Secara umum, event marketing telah mengalami pertumbuhan yang sangat cepat. Banyak organisasi bisnis telah menjadikan event marketing sebagai kesempatan atau peluang untuk menciptakan hubungan yang erat dengan pelanggan mereka. Di industri pariwisata, sebuah destinasi wisata secara langsung akan terasosiasi dengan event yang telah dilakukan. Khususnya dalam konteks konsumsi pengalaman berwisata seperti yang dijelaskan di atas, event marketing dapat memainkan peran penting dalam branding, positioning, dan mempromosikan destinasi wisata. Peran yang sangat penting dan saling melengkapi bagi terciptanya brand equity.

\section{Penciptaan pengalaman}

Dengan sifat-sifat yang dimilikinya, event marketing mempunyai kemampuan untuk langsung berhubungan dengan penciptaan pengalaman target pasarnya. Event marketing dapat dikembangkan untuk menciptakan emosi dan menawarkan kenangan pengalaman khusus yang terasosiasi dengan destinasi wisata. Hal ini bisa dilakukan dengan mencocokan jenis produk (event) dengan target pasar yang sesuai, sehingga dapat mengoptimalkan kesempatan untuk memuaskan keinginan pengunjung. Sebagai contoh, acara Solo Batik Carnival, dikembangkan untuk memenuhi kebutuhan target pasar yang spesifik, yaitu wisatawan yang suka akan produk kain batik, dan sekarang telah menjadi event karnaval yang digelar secara rutin di Solo dan mendatangkan banyak wisatawan lokal maupun mancanegara. Acara ini merespon kebutuhan target pasarnya akan acara yang sifatnya unik, dinamis, dan juga memadukan konsep suasana karnaval dengan musik dan fashion. Fakta berbicara bahwa event Solo Batik Carnival yang berlangsung di kota solo bukanlah terjadi karena suatu kebetulan. Solo sudah diakui di Mancanegara sebagai kota batik dan juga memiliki reputasi sebagai kota tujuan wisata budaya jawa.

\section{Event sebagai sebuah strategi fortifikasi}

Event marketing kemudian dapat dianggap sebagai strategi fortifikasi (memperkuat) bagi kota Solo. Tujuan dari tahap fortifikasi adalah untuk 
menghubungkan dan memperkuat citra kota Solo dengan citra dari event tersebut. Misalnya, menghubungkan event Solo Batik Carnival dengan citra kota Solo. Citra dan merek telah mewakili strategi fortifikasi yang kuat. Beberapa produk pariwisata dengan nama atau merek Solo, jika memiliki citra yang sama atau sesuai dengan citra kota Solo akan dapat saling memperkuat satu sama lain, sehingga bisa saling memberi manfaat.

Manfaat dari strategi fortifikasi merek tersebut antara lain dapat mengurangi biaya komunikasi, karena citra yang sama saling memperkuat satu sama lainnya. Event marketing yang dipromosikan lewat iklan dan upaya Public Relations kota Solo berkontribusi untuk menciptakan atau memperkuat kesadaran terhadap merek kota Solo. Dilain sisi, event marketing dapat memperkuat pengetahuan pengunjung tentang kota Solo dengan memberikan informasi yang komprehensif kepada pengunjung. Event marketing tersebut secara efektif akan membantu menyampaikan dan mempersepsikan citra kota Solo.

\section{Kontribusi terhadap kesadaran merek kota Solo}

$\begin{array}{rcr}\text { Event } & \text { marketing } & \text { sangat } \\ \text { berkontribusi } & \text { terhadap } & \text { kesadaran }\end{array}$ pengunjung potensial terhada merek kota Solo. Sebagai contoh, misalnya sebuah mega event internasional seperti Olimpiade PARA Games bisa mendatangkan banyak liputan media dan menjadi pembicaraan orang banyak. Event dalam skala yang lebih kecil mungkin tidak bisa menimbulkan kesadaran secara mendunia, tetapi festival budaya yang dikemas dengan benar dan target yang tepat bisa menghasilkan manfaat regional dan nasional yang kuat untuk awareness kota Solo. Acara tersebut bisa bertindak sebagai bentuk strategi promosi kota Solo dan memberikan kontribusi untuk menciptakan atau mempertahankan kesadaran akan merek kota Solo. Selain itu, event marketing dapat mengambil manfaat dari kegiatan public relations yang akan menghasilkan publisitas yang luas di media, lokal maupun nasional.

\section{Kontribusi terhadap persepsi kualitas}

Event PARA Games tahun 2011 di Solo, digunakan Solo untuk menjajakan potensi budayanya kepada dunia Internasional. Kota Solo mengelola event Para Games dengan sukses dan menunjukkan bahwa Solo adalah kota yang santun, berbudaya, dan mampu memberikan layanan dan produk yang berkualitas. Pengelolaan mega event yang sukses merupakan pintu untuk masyarakat dan bisnisnya. Event-event besar sudah pasti berkontribusi terhadap persepsi kualitas, namun acara yang lebih kecil dan lebih sederhana juga memberikan kontribusi persepsi kualitas. Berkat profesionalisme para pengelola dan manajer event serta kesuksesan pameran atau festival akan mencerminkan kesuksesan kota Solo. Solo, kota yang telah diuntungkan oleh image dan atribut budaya jawa dari Sejarah kerajaaan Mataram, berhasil menjadi tuan rumah dari sebuah olimpiade internasional sehingga memberikan kontribusi untuk membuat Solo dipersepsikan sebagai kota 
yang layak untuk mengelola perhelatan dalam skala internasional.

\section{Kontribusi terhadap asosiasi merk}

Asosiasi merek bisa berupa apa saja yang menghubungkan wisatawan dengan kota Solo. Hal tersebut bisa berupa citra, atribut, asosiasi, maupun brand personality. Pengelolaan merek kota Solo termasuk menentukan asosiasi apa yang pantas untuk dikembangkan dan kemudian membuat event-event yang terkait dengan asosiasi merek kota Solo tersebut. Misalnya, untuk banyak masyarakat Indonesia, Solo dikenal sebagai kota budaya yang mempunyai banyak pelaku seni pertunjukan, dan juga banyak orang yang mengasosiasikan Solo dengan festival internasional seni pertunjukan (SIPA). Ketenaran yang dinikmati oleh Solo telah ditingkatkan oleh event SIPA tersebut. Selain itu, Kota Solo yang juga telah berhasil menyelenggarakan banyak event besar yang bertaraf nasional maupun internasional, sehingga selain publisitas jangka pendek yang dihasilkan pada setiap kali event, tetapi juga reputasi jangka panjang sebagai kota budaya, serta kota yang tahu bagaimana untuk menghibur wisatawan dengan kuliner, musik, dan perayaan.

\section{Kontribusi terhadap loyalitas merek}

Loyalitas merek kota Solo adalah jantung dari ekuitas merek kota Solo. Loyalitas merek dapat didefinisikan sebagai keputusan sadar atau tidak sadar para wisatawan, yang dinyatakan melalui niat atau perilaku, untuk mengunjungi kembali kota Solo. Hal ini terjadi karena pengunjung merasakan bahwa kota Solo menawarkan fitur yang tepat atau atribut, citra, atau tingkat kualitas dengan harga yang tepat. Dalam pariwisata, harga yang harus dibayar dapat mencakup biaya aktual secara rupiah dan juag bisa berupa tingkat kesulitan untuk sampai ke Solo (waktu perjalanan dan lama tinggal). Dengan kata lain, loyalitas merek terjadi ketika kota Solo menawarkan nilai atau manfaat. Kota Solo dapat mengukur keberhasilan loyalitas merek tersebut malalui rasio banyak sedikitnya wisatawan yang mengulang kembali kunjungannya.

Event marketing menawarkan peluang untuk membuat pengunjung loyal terhadap kota Solo. Sebuah event yang menarik akan menjadi alasan kuat bagi pengunjung yang pertama kali mengunjungi kota Solo. Setelah itu, kota Solo memiliki kesempatan untuk memuaskan para pengunjungnya tersebut dan memancing mereka untuk melakukan kunjungan berikutnya. Tentu saja, event yang berulang dapat menyebabkan kembalinya pengunjung loyal. Sehingga kemudian harus diberikan keragaman konten yang cukup dari tahun ke tahun untuk menjaga agar tidak terjadinya kebosanan. Misalnya, Solo Batik Carnival menarik banyak pengunjung baru dan pengunjung loyal atau berulang selama bertahun-tahun dengan perubahan program atau konten yang variatif.

\section{Kontribusi untuk positioning kota Solo.}

Positioning melibatkan identifikasi persepsi pengunjung potensial dari atributatribut yang melekat dari kota Solo, membandingkannya dengan persepsi 
mereka terhadap atribut kota pesaing, lalu memilih atribut-atribut yang membedakan kota Solo dari para pesaingnya. Fitur-fitur atau atribut tersebut kemudian dapat disarikan untuk membentuk landasan strategi pemasaran kota Solo. Atributatribut ini bisa jadi sudah kuat melekat pada citra kota Solo (misalnya, sejarah, budaya, dan kraton) atau pemangku kebijakan pariwisata Solo dapat membuat yang baru.

Apabila dalam benak wisatawan ataupun agen wisata, sebuah event bisa diidentifikasi secara spesifik terhubung dengan kota Solo, hal tersebut bisa digunakan sebagai atribut kunci untuk mendefinisikan positioning kota Solo. Misalnya event yang dapat diidentifikasi secara unik dengan kota Solo adalah perayaan Solo Batik Carnival. Selain fungsi budaya dan tradisi, Solo Batik Carnival juga membantu positioning kota Solo sebagai kota perayaan, sebagai kota di mana lebih dari 50 kegiatan perayaan seni budaya dijadikan kalender tahunan. Ini memperkuat beberapa citra dan atribut yang ada dalam benak wisatawan secara terus menerus tentang kota Solo.

Solo sebagai sebuah brand memang sudah relatif dikenal oleh para pengunjung potensial serta Agen pariwisata. Hal ini bisa kita lihat dari tingginya pengajuan pembangunan hotel. Menurut data Badan Penanaman Modal dan Perizinan Terpadu kota Solo,dari 2011 hingga 2013, ada 42 pengajuan pembangunan hotel yang 22 pengajuan di antaranya segera memasuki masa pembangunan karena telah mengantongi izin mendirikan bangunan. Selain itu, padatnya penyelenggaraan seni budaya di kota Solo juga berdampak pada ramainya toko oleh-oleh, tempat kuliner, pusat kerajinan, pasar batik, hingga larisnya jasa pengayuh becak. Sektor usaha mikro, kecil, dan menengah bergeliat, bahkan muncul pelaku-pelaku UMKM baru. Perkembangan pariwisata kota Solo dari tahun ke tahun ditandai dengan banyaknya penyelenggaraan berbagai event budaya dan promosi pariwisata, seperti event-event budaya dan tradisi seperti Solo Batik carnival, Solo International Ethnic Music, serta event-event konferensi internasional seperti Konferensi dan Pameran Kota-kota Pusaka Dunia, Konferensi Kementerian Perumahan dan Pembangunan Perkotaan Asia Pasifik, Kongres Tahunan Ke-30 Federation ASEAN Cultural Promotion, World Toilet Summit, pertemuan praAPEC, dan PARA Games. Bahkan kota Solo sempat dinobatkan oleh Indonesia Tourism Award 2010 sebagai "kota Terfavorit" yang dikunjungi wisatawan, dan "Kota dengan Pelayanan Terbaik".

\section{PENUTUP}

\section{Kesimpulan dan Rekomendasi}

Secara global, kita melihat banyak tempat destinasi wisata yang mengembangkan strategi pemasarannya melalui penyelenggaraan event marketing. Strategi promosi dan penjualan destinasi wisata, dari hari ke hari, semakin tergantung pada penyelenggaraan event marketing. Akan tetapi, sebuah event yang mampu berperan penting dalam mewujukan tujuan pemasaran kota Solo, harus memenuhi kondisi-kondisi tertentu. Antara lain, pertama, target pasar event tersebut harus sesuai dan konsisten dengan target pasar kota Solo. Keputusan strategis harus diambil untuk menentukan jenis 
pengalaman seperti apa yang ingin dijual dan profil pengunjung yang bagaimana yang ingin ditarik oleh kota Solo.

Pengunjung yang datang ke Solo Batik Festival sangat dimungkinan untuk tertarik dengan fitur-fitur kota Solo, karena kesamaan dari penawaran produk-produk budaya, seni, kuliner, musik, dan suasana perayaannya. Citra kota Solo, "Solo the spirit of Java", konsisten dengan atribut dari festival tersebut. Oleh karena itu, pasar yang ditargetkan pun dapat digunakan bergantian oleh festival maupun kota Solo. Akan sangat aneh apabila festival yang dilakukan di kota Solo adalah Festival musik Dangdut yang secara langsung justru akan melemahkan ekuitas merek kota Solo sebagai "Solo the spirit of Java".

Akhirnya, sebagai suatu kesimpulan, semua upaya pemasaran seperti branding dan positioning adalah upaya jangka panjang. Event-event seperti Grebeg Sudiro, Sekaten Solo, Grebeg Maulud serta Solo Carnaval bukanlah sekedar sebuah acara wisata biasa. Melainkan adalah sebuah festival seni budaya masyarakat yang berakar pada tradisi yang sudah berumur lebih dari ratusan tahun. Solo Keroncong Festival merupakan juga merupakan cerminan festival komunitas dari kota yang memang dikenal sebagai kota penghasil musisi keroncong, dan dilaksanakan secara regular tiap tahun. Sehingga dibutuhkan usaha intensif untuk mengembangkan merek dan citra kota Solo. Serta kesabaran dan konsistensi untuk menyelenggarakan eventevent yang berkontribusi secara signifikan terhadap tujuan pemasaran kota Solo.

\section{DAFTAR PUSTAKA}

Aaker, D. 1991. Managing Brand Equity: Capitalizing on the Value of a Brand Name. New York : The Free Press,.

Belch, George E. and Michael A Belch. 2012, Advertising and Promotion: An Integrated Marketing Communications Perspective, Sixth Edition, New York : McGraw-Hill, Inc.

Dimanche, F. 2002. The Contribution of Special Events to Destination Brand Equity. Proceedings or European Cities Tourism's International Conference : 119-129

Dimanche, F., and D. Samdahl. 1994. Leisure as Symbolic Consumption: A Conceptualization and Prospectus for Future Research. Leisure Sciences 16: 119-129.

Getz, D. 1997. Event Management and Event Tourism., Elmsford, NY : Cognizant.

Heath, E., and G. Wall. 1992. Marketing Tourism Destinations: A Strategic Planning Approach. New York : Wiley.

Hoyle, Leonard H. 2002. Event Marketing : how a successfully promote events, festivals, conventions, and expositions. New York : John Wiley \& Sons.

Kapferer, J.N. 2008. The Strategic Brand Management, London : Kogan Page.

Kolb, Bonita M. 2006. Tourism Marketing for Cities and Towns : using branding and events to attract tourists. Oxford, UK : Elsevier. 
Lawton, G., and S. Page. 1997. Analyzing the Promotion Product and Visitors' Expectations of Urban Tourism: Auckland, New Zealand as a Case Study. Journal of Travel and Tourism Marketing 6(3/4), 54-57.

Park, C., B. Jaworski, and D. MacInnis. 1986. Strategic Brand Concept-Image Management.. Journal of Marketing 50 (October), 135-145.

Pritchard, A., and N. Morgan. 1998. 'Mood Marketing' - The New Destination Branding Strategy: A Case-Study of 'Wales' the Brand. Journal of Vacation Marketing 4(3), 215-229.

Ritchie, B., and R. Ritchie. 1998. The Branding of Tourism Destinations: Past Achievements and Future Challenges. In Destination Marketing: Scopes and Limitations, Peter Keller,ed., 48th Congress
Report. Editions AIEST, St Gall, Switzerland.

Rossiter,J.R and L.Percy. 1996. Advertising Communication and Promotion Management. New York : McGrawHill

Stanton, William.J. 1993. Fundamentals of Marketing. New York : McGraw-Hill

Tjiptono, F. 1997. Strategi Pemasaran. Yogyakarta : Penerbit Andi.

\section{INTERNET}

http://www.pariwisatasolo.surakarta.go.id.

http://www.surakarta.go.id/konten/

http://www.eventsolo.com

http://tentangsolo.web.id/calender-ofcultural-event-solo-2013

http://www.disolo.com/sekaten/ 